\title{
Investigating the relationship between work values and work ethics: A South African perspective
}

\begin{tabular}{|c|c|}
\hline \multicolumn{2}{|c|}{$\begin{array}{l}\text { Authors: } \\
\text { Petronella Jonck } \\
\text { Freda van der Walt }{ }^{2} \\
\text { Nthombi Sobayeni }^{2}\end{array}$} \\
\hline \multicolumn{2}{|c|}{$\begin{array}{l}\text { Affiliations: } \\
{ }^{1} \text { Research and Innovation } \\
\text { Unit, National School of } \\
\text { Government, South Africa }\end{array}$} \\
\hline \multicolumn{2}{|c|}{$\begin{array}{l}{ }^{2} \text { Faculty of Management } \\
\text { Sciences, Central University } \\
\text { of Technology, South Africa }\end{array}$} \\
\hline \multicolumn{2}{|c|}{$\begin{array}{l}\text { Corresponding author: } \\
\text { Freda van der Walt, } \\
\text { fvdwalt@cut.ac.za }\end{array}$} \\
\hline \multicolumn{2}{|c|}{$\begin{array}{l}\text { Dates: } \\
\text { Received: } 27 \text { Dec. } 2015 \\
\text { Accepted: } 23 \text { Nov. } 2016 \\
\text { Published: } 28 \text { Feb. } 2017\end{array}$} \\
\hline \multicolumn{2}{|c|}{$\begin{array}{l}\text { How to cite this article: } \\
\text { Jonck, P., Van der Walt, F., \& } \\
\text { Sobayeni, N. (2017). } \\
\text { Investigating the relationship } \\
\text { between work values and } \\
\text { work ethics: A South African } \\
\text { perspective. SA Journal of } \\
\text { Human Resource } \\
\text { Management/SA Tydskrif vir } \\
\text { Menslikehulpbronbestuur, } \\
\text { 15(0), a780. https://doi. } \\
\text { org/10.4102/sajhrm. } \\
\text { v15i0.780 }\end{array}$} \\
\hline \multicolumn{2}{|c|}{$\begin{array}{l}\text { Copyright: } \\
\text { (C) 2017. The Authors. } \\
\text { Licensee: AOSIS. This work } \\
\text { is licensed under the } \\
\text { Creative Commons } \\
\text { Attribution License. }\end{array}$} \\
\hline \multicolumn{2}{|l|}{ Read online: } \\
\hline 回要回 & $\begin{array}{l}\text { Scan this QR } \\
\text { code with your } \\
\text { smart phone or } \\
\text { mobile device } \\
\text { to read online. }\end{array}$ \\
\hline
\end{tabular}

Orientation: As a result of the proliferation of unethical behaviour in the workplace, the study of work ethics has received new impetus.

Research purpose: The research study sought to determine the relationship between work ethics and work values, with the objective of determining whether work ethics statistically significantly predict work values.

Motivation for the study: As work ethics (i.e. behavioural intent) are a determinant of work values (i.e. overt behaviour), researchers are investigating their potential in preventing unethical behaviour.

Research design, approach and method: A descriptive quantitative research design was employed in the study. A survey was conducted using the Multidimensional Work Ethic Profile and the Values Scale, which in previous studies have produced acceptable Cronbach's alpha coefficients. Data were collected from 301 respondents in one geographical area in South Africa.

Main findings: Work values did not appear to be highly esteemed by respondents, as only 6 of the 22 dimensions had a positive score. However, all seven dimensions of work ethics had positive scores. A negative correlation was found between work ethics and work values. In addition, work ethics predicted $9 \%$ of the variance in work values, providing sufficient evidence to accept the postulated research hypothesis.

Practical implications: The findings of the study could be used by human resource managers to promote ethical behaviour, by focusing not only on work ethics but also on the relationship between work ethics and work values.

Contribution: The study provides evidence of a relationship between work ethics and work behaviours, such as work values, within the South African context, and it thus addresses a research gap in this area.

\section{Introduction}

Unethical behaviour is a worldwide phenomenon, within increasingly unethical societies. Within these societies, individuals are required to make decisions on many different matters on a daily basis, where it is not always easy to distinguish a good decision from a bad decision. VyasDoorgapersad (2007) argues that developing countries, such as South Africa, are more susceptible to unethical behaviour because of widespread poverty, relatively low public-sector compensation, a lack of risk mechanisms (e.g. insurance and a well-developed market), opportunities created by complex, poorly defined, continually changing, and inadequate rules and regulations, a lack of properly established laws and principles, a lack of institutions to enforce a code of conduct and an absence of watchdog agencies. Unethical behaviour in South Africa, mainly in the form of corruption through bribery, has reached crisis proportions (Patel, 2013) and, as such, on a daily basis, citizens are confronted with media reports of corruption, fraudulent activities and bribery, among other things.

A study by Boshoff and Van Zyl (2011) reports that South Africa has the highest rate of whitecollar crime in the world, and that South African organisations had an average loss of income of R7.4 million due to fraud for the period 2006/2007. The Global Economic Crime Survey 2016 reports that $69 \%$ of South African organisations have experienced economic crime, and that $15 \%$ have been asked to pay a bribe (PwC, 2016). In response to recent ethics scandals, organisations are emphasising ethics awareness, or work ethics (Quesenberry, Woodburne \& Yang, 2013). However, even if an organisation has a code of ethics, ethical leadership and internal support for ethical management, this would not necessarily produce ethical behaviour (Van Vuuren, 2002). The reason for this is that while work ethics as a construct refer to attitudes and beliefs regarding 
what is ethical and what is unethical behaviour, presence or absence of work ethics does not necessarily lead to ethical or unethical behaviour (Miller, Woehr \& Hudspeth, 2002; Ravangard et al., 2014). However, previous research studies have confirmed that behavioural intent predicts actual behaviour (Kurland, 1995). Studies have also confirmed that an individual's personal values are a significant predictor of ethical behaviour (Quick \& Nelson, 2011). In addition, personal values are associated with and influence decisionmaking behaviour, and, consequently, ethical behaviour (Ivaniš \& Šturlić, 2016).

\section{Purpose}

Previous research studies have not established a consistent causal relationship between work ethics and work behaviours, such as work values (Mann, Taber \& Haywood, 2013). As such, there is a paucity of research studies that have investigated the relationship between work ethics and work values, particularly in the South African context. Given that to date no study within the South African context has been identified that has studied the aforementioned relationship, the primary objective of this study was to investigate the relationship between work ethics and work values in a South African sample. In addition, it was hypothesised that a proportion of the variance in work values can be explained by work ethics. The secondary objective was to establish which work values and which dimensions of work ethics are important in the South African work environment.

\section{Literature review}

\section{Work ethics}

The origin and make-up of the construct of ethics has been the subject of debate for millennia, and myriad philosophers has offered opinions on the topic. Although not all scholars agree, it seems reasonable to conclude that the concept of ethics is derived from the Greek word ethos, which originally referred to customs, habitual conduct, usages and character (Melden, 1967). The concept of ethics refers to the pattern, norm, or code of conduct adopted by a group of people, although the group will not necessarily obey this code of conduct (Jones, Sontag, Beckner \& Fogelin, 1977). Thus, as deviant workplace behaviour refers to violation of the norms of an organisation, one can argue that unethical behaviour equates to deviant behaviour. However, Rogojan (2009) maintains that deviant work behaviour and unethical behaviour do not necessarily constitute the same thing, as unethical behaviour is judged as wrongdoing when societal guidelines determine the morality of behaviour, not organisational norms. For the purposes of this study, however, unethical behaviour will be regarded as behaviour that is both unethical and deviant.

The construct of work ethics has its origins in the writings of the twentieth-century scholar Max Weber, which saw the conception of the construct of the Protestant work ethic (PWE) (Van Ness, Melinsky, Buff \& Seifert, 2010). The PWE, in its original manifestation, was based on four principal beliefs, namely (1) working hard is honourable and a calling from God, (2) economic success is a sign of God's grace, (3) an individual is responsible for controlling their own actions and (4) an individual should avoid any wasteful materialism that could result from hard work (Cokley et al., 2007, p. 76). The PWE has a strong religious undertone, and some may argue that it is not relevant in contemporary workplaces. However, as South Africa is still a very religious society, with people generally having strong religious convictions (Van der Walt \& De Klerk, 2015), it seems appropriate to use the PWE as the theoretical underpinning to investigate work ethics for a South African sample.

Work ethics can be defined as a productive orientation that values work as compulsory and a worthwhile life interest in order to achieve certain objectives (Bergh \& Theron, 2009). Miller et al. (2002), as well as Ravangard et al. (2014), have asserted that work ethics consists of attitudes and beliefs regarding work behaviour, and that they are a multidimensional construct that is reflected in decisionmaking and behaviour. Thus, the work ethics of employees may be regarded as the overall framework from which values emanate, where work values, in turn, potentially influence the behaviour of individuals at work. Within the context of Max Weber's original PWE theory, Miller et al. (2002) developed the Multidimensional Work Ethic Profile (MWEP) to measure seven dimensions of the construct of work ethics, namely self-reliance, morality or ethics, leisure, hard work, centrality of work, wasted time and delay of gratification (Miller et al., 2002). Self-reliance refers to striving for independence in one's everyday work (Miller et al., 2002), or depending on oneself, and not relying on others (Dwyer, 2012) (also see Van der Walt, Jonck \& Sobayeni, 2016). Morality and ethics, as measured by the MWEP, is regarded as one dimension of work ethics, and it refers to 'beliefs pertaining to a just and moral existence' (Miller et al., 2002, p. 11). However, morality and ethics are often considered as separate constructs, where morality refers to customs or manners that are usually applied to one's behaviour, and ethics relates to an individual's character (Chidi, Ogunyomi \& Badejo, 2012). Nevertheless, these two concepts are often used interchangeably to refer to the way individuals behave in the work context, or the way they are expected to behave (Van Ness et al., 2010) (also see Van der Walt et al., 2016).

Leisure refers to pro-leisure attitudes and a belief in the importance of non-work activities, such as spending time relaxing (Miller et al., 2002) or indulging in personally meaningful and pleasurable activities (Chun, Lee, Kim \& Heo, 2012) (also see Van der Walt et al., 2016). Hard work may be understood as a belief in the virtue of hard work (Miller et al., 2002), or the belief that one can become a better person and achieve objectives through commitment to the value and importance of work (Van Ness et al., 2010) (also see Van der Walt et al., 2016). Centrality of work refers to a belief in work for work's sake (Miller et al., 2002), the degree of importance that working has in the life of an individual at any given point in time, or the meaning of work (Schreuder \& Coetzee, 2011) (also see Van der Walt et al., 2016). Wasted 
time relates to attitudes and beliefs that reflect an active and productive use of time (Miller et al., 2002), that is, not wasting time on activities that will not result in production of valuable goods or services (Horman \& Kenley, 2005). Van Ness et al. (2010) explain that wasted time in the context of work ethics can be conceived of as part of a continuum, where high commitment to time management occupies one end of the continuum, and low commitment to time management occupies the other end of the continuum. Delay of gratification relates to a future orientation and postponement of rewards (Miller et al., 2002), in other words, sacrificing short-term rewards to achieve long-term objectives (Abd-El-Fattah \& AL-Nabhani, 2012) (also see Van der Walt et al., 2016). As the aforementioned dimensions of work ethics were measured, the PWE theory represents the theoretical underpinning of the study. It should be noted, however, that Stones and Philbrick (2001) cautioned that there is a paucity of systematic exploration of the PWE theory in the African context.

\section{Work values}

The literature on work values is characterised by a plethora of definitions (Steyn \& Kotze, 2004). Wils, Saba, Waxin and Labelle (2011) attribute this lack of synthesis to incomplete and inconsistent theorisation regarding the mentioned construct. As such, Wong and Yuen (2015, p. 31), citing Ros, Schwartz and Surikiss (1999), indicated that 'work values' is a term used to describe feelings, attitudes and beliefs held in regard to employment in general, and specifically various types of occupations, in addition to particular attributes, such as prestige, remuneration, job security and the work environment. Hattrup, Mueller and Joens (2007, p. 481) defined work values as beliefs about the desirability of specific outcomes related to employment. Consistent with these definitions, Ho (2006, p. 11) and Uçanok (2008, p. 157) defined work values as the goals that employees attempt to achieve through working. Wils et al. (2011), based on research conducted by various authors, stated that work values are desirable and trans-situational goals that represent a frame of reference for employees at work. Pek, Lim and Yee's (2008, p. 147) definition of work values is more comprehensive, and it states that work values consist of individual preferences for the type of work or work environment, views about the importance of the prerequisites in a work situation, and the guiding principles for job-related decision-making, action and overt behaviour.

Notwithstanding the fact, mentioned above, that Wils et al. (2011) have attributed incomplete theorisation to work values, Cogin (2012) used congruence theory as theoretical underpinning to investigate work values. Congruence theory posits that work values have a significant influence on organisational functioning, in that misalignment of the needs, demands, goals and objectives of various components within the organisation can impede organisational functioning (Cogin, 2012). However, previous research regarding work values has mostly focused on determining the dimensionality of these values, and identifying the factors that influence, or the factors that are influenced by, work values (Ueda \&
Ohzono, 2013). As such, Nord, Brief, Atieh and Doherty (1990), cited in Uçanok (2008, p. 158), suggested a twodimensional classification for work values, namely intrinsic and extrinsic work values. Intrinsic work values include values such as self-actualisation, personal growth and development, the opportunity to be creative, and use of initiative (Steyn \& Kotze, 2004). Hirschi (2010) indicated that extrinsic work values refer to high income, job security, fast and easy entry to the job, leisure time besides work, and prestigious work. Thus, intrinsic work values refer to the work that an employee does, while extrinsic work values are regarded as the outcome or consequence of employment (Twenge, Campbell, Hoffman \& Lance, 2010). Various scholars (i.e. Hirschi, 2010; Liu \& Lei, 2012; Twenge et al., 2010) have supported this dichotomous classification of work values into intrinsic and extrinsic work values.

Elizur, cited in Uçanok (2008, p. 158), developed a trichotomous classification for work values, and labelled the three categories 'instrumental values' (e.g. work conditions and benefits), 'cognitive values' (e.g. interests and achievement) and 'affective values' (e.g. relations with others). Although the terminology used for the three categories of work values posited differs among researchers, it seems that most researchers use the labels 'intrinsic values', 'extrinsic, or materialistic, values' and 'social values' to refer to the three types of work values (Sergio, Dungca \& Ormita, 2015). Ros et al. (1999) identified four dimensions of work values, namely extrinsic, intrinsic, social and power values. Power values can be defined as how much authority, influence, and prestige an employee has over others (Liu \& Lei, 2012, p. 50). Salamzadeh, Nejati and Salamzadeh (2014) proposed five dimensions of work values, including selfdevelopment, contribution to society, job satisfaction, interpersonal harmony, and work-life balance. $\mathrm{O}^{\prime}$ Connor and Kinnane (1961), cited in Liu and Lei (2012, p. 51), considered a six-dimensional classification for work values, and proposed the following classifications: security-economicmaterial values, social-artistic values, work conditions and associates, heuristic-creative values, achievement-prestige values and independence-variety values.

In light of the above discussion relating to the classification of work values, the lack of synthesis that was attributed by Wils et al. (2011) is clearly evident. Hence, it is essential that further research be conducted regarding work values, specifically with the aim of developing appropriate theories (Ueda \& Ohzono, 2013).

\section{The relationship between the constructs of work values and work ethics}

An individual's values predict attitudinal and behavioural outcomes (Rohan, 2000, cited in Montgomery, 2011) and are also regarded as a significant predictor of ethical behaviour (Quick \& Nelson, 2011). It has also been established that personal values are associated with and influence 
decision-making behaviour and, consequently, ethical behaviour (Ivaniš \& Šturlić, 2016). Although it has previously been established that personal values predict attitudinal and behavioural outcomes (Rohan, 2000, cited in Montgomery, 2011) and ethical behaviour (Ivaniš \& Šturlić, 2016; Quick \& Nelson, 2011), the current study will investigate whether work ethics predict work values. While work values are associated with work and work-related activities, work ethics, as such, refers to attitudes and beliefs, as opposed to behaviour (Miller et al., 2002; Ravangard et al., 2014). Previous research has found that attitude is the most influential factor in behavioural intent (Jafarkarimi, Saadatdoost, Sim \& Hee, 2016). This finding is consistent with the theory of reasoned action, which posits that attitude towards behaviour, together with subjective norms regarding behaviour, determines behavioural intent. Thus, employees' work ethics may be regarded as the overall framework from which work values emanate, where work values, in turn, influence individuals' behavioural intent, and potentially their behaviour at work.

Schwartz and Bilsky (1990) suggest that work ethics, specifically the PWE, are correlated with components of value systems. Quesenberry et al. (2013), Richards, Gilbert and Harris (2002), and Wittmer (2000) found that work ethics (i.e. ethical perception and intention to do the ethical thing) correlated with work values. Mann et al. (2013) indicated that research findings to date have found small but significant correlations between espousal of a work ethic and willingness to work hard, regardless of external reward (Tang, 1990), which indicates presence of intrinsic work values.

\section{Method}

A fundamental part of the research project is the research methodology employed. The methodology used in this study will be explicated in the following subsections.

\section{Research approach}

The authors used a quantitative research approach within a positivistic research orientation to achieve the research objective. More specifically, a descriptive quantitative research design was employed, so as to describe the relationship between work values and work ethics as accurately as possible at a particular point in time (Salkind, 2012). Because of the synchronic nature of this research, it could also be characterised as having employed a crosssectional research design (Leedy \& Ormrod, 2013). Wagner, Kawulich and Garner (2012) asserted that descriptive research provides a detailed picture of a relationship. The sampling design used in the research was a non-probability sampling design.

\section{Measures}

\section{Participants}

The final sample consisted of 301 respondents. Individuals were the unit of analysis, and the population parameter was working-age individuals who were either working or who had work experience, but currently unemployed. The population consisted of organisations in different sectors but situated in the same geographical area within South Africa. A convenience sampling method was employed to generate the sample, in that readily accessible potential respondents were requested to participate in the research project (Jordan, Werner \& Venter, 2015). Hence, caution is advised when generalising the findings to the larger population, due to the fact that a non-random sampling technique was employed, which would adversely affect the external validity of the study (Wagner et al., 2012).

Of the 540 questionnaires distributed, 301 were completed and returned, which translates to a response rate of $55.7 \%$. The self-administered questionnaire was distributed (to be returned anonymously) by the researcher. Where possible, the researcher personally collected the questionnaires, which were placed in a sealed envelope, on a pre-arranged day and time. Respondents were given 14 days to complete the questionnaire at their own convenience.

\section{Measuring instrument}

Two unabridged questionnaires were administered, accompanied by a self-constructed biographical questionnaire.

Biographical questionnaire: The biographical questionnaire was designed by the researchers in a way that it would solicit relevant demographic information from the participants in terms of their age, sex, race, employment tenure, generational cohort and highest academic qualification.

The Values Scale: When it was first developed, the aim of the Values Scale (VS) was to understand the needs that respondents experience, and to assess the relative importance of the work role as a means of needs satisfaction, given the context of other life roles (Langley, Du Toit \& Herbst, 1992). Thus, the aim of the VS is to determine the value of certain work-related aspects to individual respondents. The VS (Langley et al., 1992) comprises 110 items in a Likert-scale format, with response categories ranging from 1 ('of little importance') to 4 ('very important'). The VS measures 22 aspects relating to work, namely ability utilisation, achievement, advancement, aesthetics, altruism, authority, autonomy, creativity, cultural identity, economic rewards, economic security, own lifestyle, personal development, physical activities, physical prowess, prestige, risk, social interaction, social relationships, spirituality, variety and agreeable working conditions. A sample item is 'I find pleasure in the beauty of my work', which is an example from the aesthetics dimension. Another example is 'I make my own decisions at work', which represents the autonomy dimension of work values. Within a South African context, Boonzaier (2008) and Langley et al. (1992) reported acceptable Cronbach's alpha coefficients. Langley et al. (1992) reported an inter-item correlation coefficient of 0.7 .

The Multidimensional Work Ethic Profile: The 65-item MWEP was developed by Miller et al. (2002, p. 1), and it 
'measures seven conceptually and empirically distinct dimensions of the work ethic construct'. Items for each subscale include the following: 'To be truly successful, a person should be self-reliant' (self-reliance), 'One should always take responsibility for one's actions' (morality or ethics), 'Life would be more meaningful if we had more leisure time' (leisure), 'Nothing is impossible if you work hard enough' (hard work), 'I feel uneasy when there is little work for me to do' (centrality of work), 'It is important to stay busy at work and not waste time' (wasted time), and 'If I want to buy something, I always wait until I can afford it' (delay of gratification). The questionnaire followed a Likerttype format, with response categories ranging from 'strongly agree' to 'strongly disagree'. The instruction to participants was to provide responses based on their opinion or belief about each item. The MWEP has previously been subjected to psychometric validation (Van Ness et al., 2010). Miller et al. (2002) reported the following Cronbach's alpha values: 0.89 (self-reliance), 0.80 (morality or ethics), 0.85 (leisure), 0.83 (hard work), 0.81 (centrality of work), 0.80 (wasted time) and 0.76 (delay of gratification).

Reliability and validity of the study: Cronbach's alpha coefficients were used to calculate the inter-item consistency of the two measuring instruments (the results are depicted in Table 1). From these results, it can be concluded that the scores obtained from the two instruments used were very reliable, as scores of 0.95 and 0.94 were obtained for the VS and the MWEP, respectively. More specifically, the reliability values for the various dimensions of the VS were as follows: $\alpha=0.64$ (ability utilisation), $\alpha=0.66$ (achievement), $\alpha=0.61$ (advancement), $\alpha=0.63$ (aesthetics), $\alpha=0.75$ (altruism), $\alpha=0.63$ (authority), $\alpha=0.62$ (autonomy), $\alpha=0.69$ (creativity), $\alpha=0.72$ (cultural identity), $\alpha=0.73$ (economic reward), $\alpha=0.69$ (economic security), $\alpha=0.64$ (own lifestyle), $\alpha=0.60$ (personal development), $\alpha=0.73$ (physical activities), $\alpha=0.76$ (physical prowess), $\alpha=0.68$ (prestige), $\alpha=0.67$ (risk), $\alpha=0.65$ (social interaction), $\alpha=0.66$ (social relations), $\alpha=0.65$ (spirituality), $\alpha=0.70$ (variety) and $\alpha=0.55$ (agreeable working conditions). The reliability values for each sub-construct of the MWEP were as follows: $\alpha=0.66$ (self-reliance), $\alpha=0.87$ (leisure), $\alpha=0.75$ (hard work), $\alpha=0.78$ (centrality of work), $\alpha=0.77$ (wasted time) and $\alpha=0.71$ (delay of gratification).

Validity refers to the degree to which a measuring instrument determines what it is supposed to determine, by gathering relevant data on the constructs under investigation (Jordan et al., 2015). In this research, the relevant constructs are work ethics and work values. Two types of validity were pursued, namely content validity and face validity, particularly considering that previous research findings have confirmed the psychometric properties of the unabridged questionnaires.

\begin{tabular}{|c|c|c|}
\hline Scale & Number of items & Cronbach's alpha \\
\hline VS (Work values) & 110 & 0.95 \\
\hline MWEP (Work ethics) & 65 & 0.94 \\
\hline
\end{tabular}

VS, Values Scale; MWEP, Multidimensional Work Ethic Profile.
To ensure face validity of the questionnaires, they were distributed to two experts in the field of human resource management, who also confirmed the content validity of the instruments. A pilot study with ten respondents from the target population was conducted to further ensure the face validity of the questionnaires. The aim was to check for any ambiguous, biased or leading questions, and to determine the minimum time required to complete the questionnaire. No changes to the measuring instrument were indicated by the pilot study participants. In addition, a statistician reviewed the questionnaire in terms of its format and layout, and the suitability of the items for statistical analysis.

Factor analysis results to determine the construct validity of the VS indicated that the data were factorable, as the KaiserMeyer-Olkin (KMO) test for sampling adequacy returned a value of 0.824 , and Bartlett's test of sphericity returned a statistically significant value, on the 99th percentile $\left(X^{2}=\right.$ 15 701.176; $\left.d f=5995 ; p=0.000^{* *}\right)$. An exploratory factor analysis with oblique (oblimin) rotation was employed, and it was determined that 30 components had an eigenvalue exceeding 1, accounting for $68.160 \%$ of the total variance. However, an inspection of the scree plot indicated a clear break after the fourth factor. It was thus decided to retain four components for purposes of further investigation in a Monte Carlo parallel analysis. Results obtained from the analysis indicated that four components had eigenvalues exceeding the corresponding criterion value for a randomly generated data matrix of the same size (110 variables $\times 301)$. The aforementioned results lend support to the notion that the subscales can be used as unidimensional factors.

In the same way, a factor analysis was performed to determine the construct validity of the MWEP. The results indicated that the data were factorable, with a KMO of 0.830, and a Bartlett's test of sphericity value that was statistically significant, on the 99th percentile $\left(X^{2}=7442.558 ; d f=2080 ; p=0.000^{* *}\right)$. The exploratory factor analysis with oblique rotation indicated that 19 components had an eigenvalue exceeding 1, accounting for $65.662 \%$ of the total variance. The scree plot, however, indicated the presence of seven factors, while the Monte Carlo parallel analysis results indicated that eight components had eigenvalues exceeding the corresponding criterion value for a randomly generated data matrix of the same size $(65$ variables $\times 301)$. The results should be interpreted in the light of the fact that the MWEP measures seven conceptually and empirically distinct dimensions of the work ethic construct (Miller et al., 2002) with one general dimension that all the items load onto.

\section{Analysis}

Data were analysed using Statistical Package for the Social Sciences (SPSS) version 20. First, Cronbach's alpha coefficients were computed for the VS and the MWEP. Descriptive statistics included frequency distributions, measures of central tendency and measures of dispersion. Inferential statistics included a Pearson product-moment correlation, to ascertain the relationship between the 
constructs, and a multiple regression analysis, to assess whether work values predicted work ethics.

Ethical considerations: Prior to data collection, ethical clearance was obtained from the research faculty committee of the institution concerned. Permission was also granted by the organisations at which the respondents were employed at the time of data gathering. Lastly, participant signed consent was obtained before commencing with data collection. Standard ethical guidelines were adhered to.

\section{Results}

The descriptive statistics and the inferential statistics results are reported separately in this section.

\section{Demographic characteristics}

The sample group consisted of mostly African (91.4\%) female $(62.5 \%)$ respondents between the ages of 18 and 23 years $(51.5 \%)$. Respondents with 1 year or less of service made up $44.2 \%$ of the sample, and those with a Grade 12 qualification made up $62.8 \%$ of the sample. Table 2 depicts the demographic profile of the sample.

\section{Prevalence of work values and work ethics}

The findings of the study, as illustrated in Table 3, reveal that respondents did not esteem work values highly.

The mean scores of the following dimensions of work values were above the median, and were thus positive: authority $(\mathrm{M}=14.23 ; \mathrm{SD}=2.780)$, creativity $(\mathrm{M}=16.07 ; \mathrm{SD}=2.541)$, economic security $(\mathrm{M}=17.02 ; \mathrm{SD}=2.408)$, prestige $(\mathrm{M}=16.12 ; \mathrm{SD}=2.894)$, risk $(\mathrm{M}=12.11 ; \mathrm{SD}=3.377)$, social relationships $(\mathrm{M}=13.20$; $\mathrm{SD}=3.116)$. However, the mean scores of the following work value subscales were below the median, and these dimensions of work values were thus

\begin{tabular}{|c|c|c|c|}
\hline Category & Variable & $n$ & $\%$ \\
\hline \multirow[t]{2}{*}{ Sex } & Male & 112 & 37.2 \\
\hline & Female & 188 & 62.5 \\
\hline \multirow[t]{4}{*}{ Population group } & African & 275 & 91.4 \\
\hline & White & 17 & 5.6 \\
\hline & Coloured & 7 & 2.3 \\
\hline & Indian/Asian & 1 & 0.3 \\
\hline \multirow[t]{3}{*}{ Age } & $13-23$ years & 155 & 51.5 \\
\hline & $24-43$ years & 112 & 37.2 \\
\hline & $44-63$ years & 34 & 11.3 \\
\hline \multirow[t]{5}{*}{ Years of service } & $0-1$ years & 133 & 44.2 \\
\hline & $2-5$ years & 114 & 37.9 \\
\hline & $6-10$ years & 24 & 8.0 \\
\hline & $11-15$ years & 8 & 2.7 \\
\hline & $15+$ years & 17 & 5.6 \\
\hline \multirow{6}{*}{$\begin{array}{l}\text { Highest academic } \\
\text { qualification }\end{array}$} & Below Grade 12 & 10 & 3.3 \\
\hline & Grade 12 & 189 & 62.8 \\
\hline & National diploma & 70 & 23.3 \\
\hline & $\begin{array}{l}\text { Honours/bachelor's } \\
\text { degree }\end{array}$ & 23 & 7.6 \\
\hline & Master's degree & 7 & 2.3 \\
\hline & Doctorate & 1 & 0.3 \\
\hline
\end{tabular}

not highly valued by the respondents: ability $(\mathrm{M}=17.73$; $\mathrm{SD}=2.228)$, achievement $(\mathrm{M}=17.41 ; \mathrm{SD}=2.251)$, advancement $(\mathrm{M}=17.47 ; \mathrm{SD}=2.235)$, aesthetics $(\mathrm{M}=15.75$; $\mathrm{SD}=2.805)$, altruism $(\mathrm{M}=16.48 ; \mathrm{SD}=2.723)$, autonomy $(\mathrm{M}=14.46 ; \mathrm{SD}=3.019)$, cultural identity $(\mathrm{M}=14.83$; $\mathrm{SD}=3.282)$, economic rewards $(\mathrm{M}=16.87 ; \mathrm{SD}=2.856)$, own lifestyle $(\mathrm{M}=15.31 ; \mathrm{SD}=2.873)$, personal development $(\mathrm{M}=17.40 ; \mathrm{SD}=2.173)$, physical activities $(\mathrm{M}=14.86$; $\mathrm{SD}=3.111)$, physical prowess $(\mathrm{M}=12.71 ; \mathrm{SD}=3.526)$, social interaction $(\mathrm{M}=14.66 ; \mathrm{SD}=2.825)$, spirituality $(\mathrm{M}=15.81$; $\mathrm{SD}=2.645)$, variety $(\mathrm{M}=14.79 ; \mathrm{SD}=2.967)$ and working conditions $(\mathrm{M}=15.52 ; \mathrm{SD}=2.669)$. From the above findings, it would appear that respondents indicated the above values as 'very important', except for the values of cultural identity, risk, social interaction, social relationships, and variety, which were perceived as 'important'. As far as the mean scores for the dimensions of work ethics are concerned, respondents scored positively on all the dimensions, namely self-reliance $(M=20.50 ; S D=5.283)$, morality or ethics $(\mathrm{M}=23.21 ; \mathrm{SD}=4.363)$, leisure $(\mathrm{M}=28.20 ; \mathrm{SD}=8.110)$, hard work $(M=16.10 ; \mathrm{SD}=5.183)$, centrality of work $(\mathrm{M}=20.94$; $\mathrm{SD}=5.980)$, wasted time $(\mathrm{M}=15.60 ; \mathrm{SD}=4.663)$, and delay of gratification $(\mathrm{M}=14.82 ; \mathrm{SD}=4.514)$.

\section{Pearson correlation analysis}

To investigate the intercorrelations between the various work values and work ethics subscales, a Pearson product-moment correlation was calculated, to identify significant relationships between the subscales of work values and those of work ethics. It should be noted that normality was assumed. Due to the high number of variables involved in the research, 29 altogether, results will only be discussed, and not illustrated. Most of the correlations were significant and negative on either the 99th or the 95th percentile, for example, the work ethics dimension of self-reliance had weak intercorrelations (according to guidelines as given in Pallant [2011, p. 134], who indicated that an $r$-value of between 0.10 and 0.29 can be considered as weak) with ability utilisation ( $p \leq 0.037^{*}$; $r=-0.120)$, achievement $(p \leq 0.039 * ; r=-0.119)$, aesthetics $\left(p \leq 0.004^{* *} ; r=-0.168\right)$, authority $\left(p \leq 0.017^{*} ; r=-0.138\right)$, autonomy $\left(p \leq 0.000^{* *} ; r=-0.207\right)$, cultural identity $\left(p \leq 0.003^{* *} ; r=-0.172\right)$, economic security $(p \leq 0.003 * *$; $r=-0.170)$, own lifestyle $(p \leq 0.000 * * ; r=-0.205)$ and working conditions ( $\left.p \leq 0.006^{* *} ; r=-0.157\right)$, to mention a few. As far as the dimensions of work ethics are concerned, morality/ethics had weak intercorrelations with, among others, aesthetics $(p \leq 0.006 * * ; r=-0.157)$, own lifestyle $(p \leq 0.006 ; r=-0.158)$, physical prowess $(p \leq 0.009 * * ; r=-0.151)$, risk $(p \leq 0.000 * *$; $r=-0.240)$, social interaction $\left(p \leq 0.001^{* *} ; r=-0.183\right)$, social relationships $\left(p \leq 0.000^{* *} ; r=-0.230\right)$ and spirituality $(p \leq 0.002 * * ; r=-0.179)$. The work ethics dimension of leisure had weak intercorrelations with autonomy $(p \leq 0.000 * *$; $r=-0.237)$, cultural identity $\left(p \leq 0.000^{* *} ; r=-0.201\right)$, own lifestyle $(p \leq 0.000 * * ; r=-0.209)$, risk $(p \leq 0.000 * * ; r=-0.219)$, and social relationships $\left(p \leq 0.000^{* *} ; r=-0.280\right)$. Similarly, the work ethics dimension of hard work correlated weakly with ability utilisation $(p \leq 0.000 * * ; r=-0.267)$, achievement $(p \leq 0.000 * * ; r=-0.266)$, advancement $\left(p \leq 0.000^{* *} ; r=-0.263\right)$, 
TABLE 3: Measures of central tendency and dispersion - work values and work ethics.

\begin{tabular}{|c|c|c|c|c|c|c|c|}
\hline Factor & Item & Mean & SD & $60 \%$ & Min & Median $(50 \%)$ & Max \\
\hline \multirow[t]{20}{*}{ Work values } & Ability utilisation & 17.73 & 2.228 & 19 & 5 & 18 & 20 \\
\hline & Achievement & 17.41 & 2.251 & 18 & 5 & 18 & 20 \\
\hline & Advancement & 17.47 & 2.235 & 18 & 5 & 18 & 20 \\
\hline & Aesthetics & 15.75 & 2.805 & 17 & 6 & 16 & 20 \\
\hline & Altruism & 16.48 & 2.723 & 17 & 6 & 17 & 20 \\
\hline & Authority & 14.23 & 2.780 & 15 & 6 & 14 & 20 \\
\hline & Creativity & 16.07 & 2.541 & 17 & 7 & 16 & 20 \\
\hline & Cultural identity & 14.83 & 3.282 & 16 & 5 & 15 & 20 \\
\hline & Economic rewards & 16.87 & 2.856 & 18 & 6 & 17 & 20 \\
\hline & Economic security & 17.02 & 2.408 & 18 & 5 & 17 & 20 \\
\hline & Own lifestyle & 15.31 & 2.873 & 16 & 8 & 16 & 20 \\
\hline & Personal development & 17.40 & 2.173 & 18 & 8 & 18 & 20 \\
\hline & Physical activities & 14.86 & 3.111 & 16 & 5 & 15 & 20 \\
\hline & Prestige & 16.12 & 2.894 & 17 & 5 & 16 & 20 \\
\hline & Risk & 12.11 & 3.377 & 13 & 5 & 12 & 20 \\
\hline & Social interaction & 14.66 & 2.825 & 15 & 6 & 15 & 20 \\
\hline & Social relationships & 13.20 & 3.116 & 14 & 6 & 13 & 20 \\
\hline & Spirituality & 15.81 & 2.645 & 17 & 6 & 16 & 20 \\
\hline & Variety & 14.79 & 2.967 & 16 & 6 & 15 & 20 \\
\hline & Working conditions & 15.52 & 2.669 & 16 & 5 & 16 & 20 \\
\hline \multirow[t]{7}{*}{ Work ethics } & Self-reliance & 20.50 & 5.283 & 21 & 10 & 20 & 44 \\
\hline & Morality/ethics & 23.21 & 4.363 & 24 & 10 & 23 & 41 \\
\hline & Leisure & 28.20 & 8.110 & 30 & 10 & 28 & 49 \\
\hline & Hard work & 16.10 & 5.183 & 17 & 9 & 15 & 45 \\
\hline & Centrality of work & 20.94 & 5.980 & 22 & 10 & 20 & 45 \\
\hline & Wasted time & 15.60 & 4.663 & 16.20 & 6 & 15 & 37 \\
\hline & Delay of gratification & 14.82 & 4.514 & 15 & 6 & 14 & 35 \\
\hline
\end{tabular}

creativity ( $\left.p \leq 0.000^{* *} ; r=-0.202\right)$, economic security $(p \leq 0.000 * * ; r=-0.225)$, personal development $(p \leq 0.000 * *$; $r=-0.234)$, prestige $(p \leq 0.000 * * ; r=-0.209)$, spirituality $\left(p \leq 0.000^{* *} ; r=-0.234\right)$ and variety $(p \leq 0.000 * * ; r=-0.212)$. The dimension of centrality of work correlated weakly with aesthetics $(p \leq 0.000 * * ; r=-0.208)$, altruism $(p \leq 0.000 * *$; $r=-0.291)$, physical activities $(p \leq 0.000 * * ; r=-0.246)$, physical prowess ( $p \leq 0.000 * * ; r=-0.215)$, and spirituality ( $p \leq 0.000$; $r=-0.283)$. The dimension of wasted time correlated weakly with altruism ( $p \leq 0.000 * * ; r=-0.243)$, physical activities $\left(p \leq 0.000^{* *} ; r=-0.218\right)$ and spirituality $\left(p \leq 0.000^{* *}\right.$; $r=-0.252)$, to mention a few. Lastly, the dimension of delay of gratification correlated weakly with aesthetics $(p \leq 0.000 * *$; $r=-0.213)$, altruism $(p \leq 0.000 * * ; r=-0.219)$, physical prowess $\left(p \leq 0.000^{* *} ; r=-0.239\right)$, risk $(p \leq 0.000 * * ; r=-0.222)$ and spirituality $\left(p \leq 0.000^{* *} ; r=-0.256\right)$.

Because of the large amount of information, the data were reduced by categorising the 22 work values into four categories (Ros et al. [1999] recommend that data be reduced when there is a large amount of information), on the basis of the factor analysis results reported on in the methodology section. The factor analysis results indicated the presence of four factors. The four dimensions of work values were extrinsic, intrinsic, social and power values. The category of intrinsic work values consisted of ability utilisation, achievement, creativity, own lifestyle, personal development, spirituality and variety. The extrinsic work values category included advancement, aesthetics, economic rewards, economic security, physical activities, physical prowess, risk and agreeable working conditions. The social work values category consisted of altruism, cultural identity, social interaction and social relationships. Lastly, the power work values category included authority, autonomy and prestige. The reliability for the total scale was 0.88 , while the reliability for the four dimensions of work values was as follows: $\alpha=0.86$ (intrinsic work values), $\alpha=0.78$ (extrinsic work values), $\alpha=0.70$ (social work values), and $\alpha=0.66$ (power work values).

The results of the Pearson product-moment correlations for the four dimensions of work values and the seven work ethics subscales are depicted in Table 4.

As can be seen from Table 4, most of the work ethics dimensions exhibited medium to strong correlations with each other, with the exception of the dimension of leisure. Leisure did not correlate with hard work, centrality of work and wasted time. These results can be expected. The four dimensions of work values displayed strong positive relationships with each other. For example, extrinsic and intrinsic work values were found to intercorrelate, with an $r$-value of 0.735 , which indicates a strong positive relationship (Pallant, 2011), and the relationship was statistically significant, on the 99th percentile. There was also a strong positive correlation between power work values and intrinsic work values $(r=0.703 ; p \leq 0.000 * *)$. It is interesting to note that the four dimensions of work values correlated negatively 
TABLE 4: Pearson product-moment correlations between measures of work values and work ethics.

\begin{tabular}{|c|c|c|c|c|c|c|c|c|c|c|c|}
\hline Subscale & 1 & 2 & 3 & 4 & 5 & 6 & 7 & 8 & 9 & 10 & 11 \\
\hline Self-reliance (1) & - & - & - & - & - & - & - & - & - & - & - \\
\hline \multirow[t]{2}{*}{ Morality/ethics (2) } & $r=0.453$ & - & - & - & - & - & - & - & - & - & - \\
\hline & $p=0.000 * *$ & & & & & & & & & & \\
\hline \multirow[t]{2}{*}{ Leisure (3) } & $r=0.364$ & $r=0.347$ & - & - & - & - & - & - & - & - & - \\
\hline & $p=0.000 * *$ & $p=0.000 * *$ & & & & & & & & & \\
\hline Hard work (4) & $r=0.492$ & $r=0.368$ & $r=0.023$ & - & - & - & - & - & - & - & - \\
\hline \multirow[t]{2}{*}{ Centrality of work (5) } & $r=0.304$ & $r=0.331$ & $r=-0.109$ & $r=0.431$ & - & - & - & - & - & - & - \\
\hline & $p=0.000 * *$ & $p=0.000 * *$ & $p=0.059$ & $p=0.000 * *$ & & & & & & & \\
\hline \multirow[t]{2}{*}{ Wasted time (6) } & $r=0.345$ & $r=0.368$ & $r=-0.077$ & $r=0.511$ & $r=0.691$ & - & - & - & - & - & - \\
\hline & $p=0.000 * *$ & $p=0.000 * *$ & $p=0.186$ & $p=0.000 * *$ & $p=0.000 * *$ & & & & & & \\
\hline \multirow[t]{2}{*}{ Delay of gratification (7) } & $r=0.375$ & $r=0.395$ & $r=0.124$ & $r=0.504$ & $r=0.513$ & $r=0.593$ & - & - & - & - & - \\
\hline & $p=0.000 * *$ & $p=0.000 * *$ & $p=0.031^{*}$ & $p=0.031 *$ & $p=0.000 * *$ & $p=0.000 * *$ & & & & & \\
\hline Intrinsic work values (8) & $r=-0.164$ & $r=-0.159$ & $r=-0.124$ & $r=-0.299$ & $r=-0.152$ & $r=-0.156$ & $r=-0.180$ & - & - & - & - \\
\hline \multirow[t]{2}{*}{ Extrinsic work values (9) } & $r=-0.181$ & $r=-0.156$ & $r=-0.138$ & $r=-0.210$ & $r=-0.245$ & $r=-0.182$ & $r=-0.242$ & $r=0.73$ & - & - & - \\
\hline & $p=0.002 * *$ & $p=0.007 * *$ & $p=0.017^{*}$ & $p=0.000 * *$ & $p=0.000 * *$ & $p=0.002 * *$ & $p=0.000 * *$ & $p=0.000 * *$ & & & \\
\hline \multirow[t]{2}{*}{ Social work values (10) } & $r=-0.119$ & $r=-0.219$ & $r=-0.195$ & $r=-0.158$ & $r=-0.197$ & $r=-0.150$ & $r=-0.224$ & $r=0.633$ & $r=0.648$ & - & - \\
\hline & $p=0.038^{*}$ & $p=0.000 * *$ & $p=0.001 * *$ & $p=0.006^{* *}$ & $p=0.001 * *$ & $p=0.009 * *$ & $p=0.000 * *$ & $p=0.000 * *$ & $p=0.000 * *$ & & \\
\hline \multirow[t]{2}{*}{ Power work values (11) } & $r=-0.200$ & $r=-0.132$ & $r=-0.185$ & $r=-0.177$ & $r=-0.054$ & $r=-0.039$ & $r=-0.116$ & $r=0.703$ & $r=0.666$ & $r=0.540$ & - \\
\hline & $p=0.000 * *$ & $p=0.022 *$ & $p=0.001 * *$ & $p=0.002^{* *}$ & $p=0.351$ & $p=0.503$ & $p=0.044 *$ & $p=0.000 * *$ & $p=0.000 * *$ & $p=0.000 * *$ & \\
\hline
\end{tabular}

${ }^{*} p \leq 0.05 ;{ }^{* *} p \leq 0.01$ (two-tailed).

with the seven dimensions of work ethics. This means that if work values increase, there is a decrease in work ethics, and vice versa. The correlations were mostly weak. For example, there was a weak negative relationship between power work values and self-reliance, as is evident from the $r$-value of -0.200 . However, the relationship was statistically significant, on the 99th percentile.

\section{Multiple regression analysis}

Multiple regression analysis was conducted to investigate the multivariate relationship between the independent variable of work ethics and the dependent variables of intrinsic work values, extrinsic work values, social work values, and power work values. It was hypothesised that work ethics statistically significantly predict the various work values, as stated above. The results of the multiple regression analysis are presented in Table 5.

The results presented in Table 5 indicate that work ethics predicted $5.7 \%$ of the variance in intrinsic work values, as is evident from the multiple $R^{2}$-value of $0.057(\beta=-0.239$; $\left.p=0.000^{* *}\right)$. In addition, work ethics was responsible for $8.7 \%$ of the variance in extrinsic work values (multiple $\left.R^{2}=0.087 ; \beta=-0.296 ; p=0.000 * *\right), 7.9 \%$ of the variance in social work values (multiple $R^{2}=0.079 ; \beta=-0.280$; $p=0.000 *)$, and $4.3 \%$ of the variance in power work values (multiple $R^{2}=0.043 ; \beta=-0.207 ; p=0.000^{*}$ ). The relationship was statistically significant, as the $p$-values were all less than 0.01 , which indicates statistical significance, on the 99th percentile. The negative coefficient implied that positive work ethics will most probably result in negative work values in an organisation. The results provide support for the assumption that there is a significant relationship between work ethics and work values in respondents included in the sample.

\section{Discussion \\ Outline of results}

The findings suggest that not all the work values that were measured were highly regarded by respondents. This is evident from the fact that respondents had positive scores on only 6 of the 22 work values measured, namely authority, creativity, economic security, prestige, risk and social relationships. It is somewhat unusual for employees to value both authority and social relationships, because authority is positively related to Machiavellianism, which is regarded as an antisocial interpersonal style associated with strategic manipulation (Niemi \& Young, 2013). Palmer (1983) offers a similar argument, when she states that authority is associated with power (i.e. the capacity to control the behaviour of others), which impedes helping or caring relationships. Furthermore, while people often gain power through traits and actions such as empathy, collaboration, openness, fairness, and sharing, once they wield power, they are more likely to engage in rude, selfish, and unethical behaviour (Keltner, 2016).

In terms of work ethics, respondents had positive scores on all seven dimensions of work ethics that were measured, namely self-reliance, morality/ethics, leisure, hard work, centrality of work, wasted time and delay of gratification. This shows that the PWE is still relevant. Having said this though, the majority of the sample was African (91.4\%), and African values include being a good member of the community, living and enjoying life, belonging to a group, group recognition, accountability towards the community and 'ubuntu' (the belief that a person is only a person through their relations with other people) (Du Plessis \& Rousseau, 2005). In contrast with traditional African values, European (or Western) values focus more on individualism, materialism, achievement, success, self-reliance, self-interest, 
TABLE 5: Multiple regression analysis results.

\begin{tabular}{|c|c|c|c|c|c|c|c|}
\hline Dependent variable & Item & Unstandardised regression coefficient & Beta (ß) & Std error of coefficient & $t(301)$ & $p$ & Value \\
\hline \multirow[t]{8}{*}{ Intrinsic work values } & Intercept & 132.012 & - & 4.176 & 31.609 & $0.000 * *$ & - \\
\hline & Work ethics & -0.126 & -0.239 & 0.030 & -4.254 & $0.000 * *$ & - \\
\hline & Multiple $R$ & - & - & - & - & - & 0.239 \\
\hline & Multiple $R^{2}$ & - & - & - & - & - & 0.057 \\
\hline & Adjusted $R^{2}$ & - & - & - & - & - & 0.054 \\
\hline & $F$-value & - & - & - & - & - & 18.10 \\
\hline & $p$-value & - & - & - & - & - & $0.000 * *$ \\
\hline & Std error of estimate & - & - & - & - & - & 12.527 \\
\hline \multirow[t]{8}{*}{ Extrinsic work values } & Intercept & 146.336 & - & 4.555 & 3.129 & $0.000 * *$ & - \\
\hline & Work ethics & -0.172 & -0.296 & 0.032 & -5.354 & $0.000 * *$ & - \\
\hline & Multiple $R$ & - & - & - & - & - & 0.296 \\
\hline & Multiple $R^{2}$ & - & - & - & - & - & 0.087 \\
\hline & Adjusted $R^{2}$ & - & - & - & - & - & 0.084 \\
\hline & $F$-value & - & - & - & - & - & 28.668 \\
\hline & $p$-value & - & - & - & - & - & $0.000^{* *}$ \\
\hline & Std error of estimate & - & - & - & - & - & 13.661 \\
\hline \multirow[t]{8}{*}{ Social work values } & Intercept & 146.336 & - & 2.760 & 26.416 & $0.000 * *$ & - \\
\hline & Work ethics & -0.172 & -0.296 & 0.020 & -5.053 & $0.000 * *$ & - \\
\hline & Multiple $R$ & - & - & - & - & - & 0.280 \\
\hline & Multiple $R^{2}$ & - & - & - & - & - & 0.079 \\
\hline & Adjusted $R^{2}$ & - & - & - & - & - & 0.076 \\
\hline & $F$-value & - & - & - & - & - & 25.531 \\
\hline & $p$-value & - & - & - & - & - & $0.000 * *$ \\
\hline & Std error of estimate & - & - & - & - & - & 8.278 \\
\hline \multirow[t]{8}{*}{ Power work values } & Intercept & 52.723 & - & 2.193 & 24.040 & $0.000 * *$ & - \\
\hline & Work ethics & -0.057 & -0.207 & 0.015 & -3.666 & $0.000 * *$ & - \\
\hline & Multiple $R$ & - & - & - & - & - & 0.207 \\
\hline & Multiple $R^{2}$ & - & - & - & - & - & 0.043 \\
\hline & Adjusted $R^{2}$ & - & - & - & - & - & 0.040 \\
\hline & $F$-value & - & - & - & - & - & 13.441 \\
\hline & $p$-value & - & - & - & - & - & $0.000 * *$ \\
\hline & Std error of estimate & - & - & - & - & - & 6.578 \\
\hline
\end{tabular}

$n=301 ; * p \leq 0.01$.

self-confidence, self-esteem and self-fulfilment, which have a PWE undertone (Du Plessis \& Rousseau, 2005). One may argue that Africans have had to conform to and adopt Western values, which are subscribed to in many South African organisations, to be recognised and rewarded in these workplaces, and that this may consequently influence their ethical behaviour.

In terms of the specific dimensions of work values that were measured, valuing delay of gratification may show that individuals are becoming increasingly concerned about the future, as a result of the global and national economic decline. Showing high regard for self-reliance and hard work in a capitalist country, such as South Africa, is not surprising, as capitalism promotes and rewards individualism. Despite centrality of work and hard work being held in high regard by the sample, leisure and wasted time were also regarded as important. This shows that although the sample values work and working hard, they also enjoy spending time on personal activities that are meaningful, pleasurable and relaxing.

The positive scores on morality or ethics are surprising, but pleasing if one considers that ethics and morality are essential to make ethical decisions and uphold moral behaviour in the workplace (Bowden \& Smythe, 2008; Bowen, 2005). Furthermore, it would seem that ethics and morality are particularly important in a country such as South Africa, where societal and business leaders are increasingly encountering unethical behaviour. Therefore, creating strong ethical organisational cultures is necessary to support ethical behaviour. In addition, employees need to be coached by mentors in morality and/or ethics, so as to create a common understanding thereof. In a study by McManus and Subramaniam (2009), it was found that unethical behaviour is affected by mentoring support and the perceived standard of ethical conduct by peers. Similarly, new employees entering the workplace need to be coached during induction programmes, so as to preserve strong ethical organisational cultures, which are embraced by all organisational members.

The initial correlation coefficient indicated various intercorrelations ranging from strong (e.g. between achievement and ability utilisation $-r=0.73 ; p \leq 0.000)$ to weak (e.g. between economic rewards and altruism $r=0.217 ; p \leq 0.000)$. To reduce the large amount of data, the 22 work values were categorised into four overarching values, namely extrinsic, intrinsic, social and power work values. A second Pearson product-moment correlation revealed a weak negative correlation between the four work values and the seven dimensions of work ethics. Despite the weakness of the relationship, the $p$-value did indicate statistical significance. The aforementioned finding confirms 
Schwartz and Bilsky's (1990) finding that there is a correlation between work ethics and work values. Similarly, Quesenberry et al. (2013), Richards et al. (2002), and Wittmer (2000) found that work ethics (i.e. ethical perception, and intention to do the ethical thing) correlated with work values (i.e. overt behaviour), while Tang (1990), as cited in Mann et al. (2013), reported a small but significant correlation between work ethics and intrinsic work values. However, the direction of the relationship was not mentioned.

The results from the regression analysis confirm negative statistically significant relationships between work ethics and the four dimension of work values. It should, however, also be noted that the respondents did not place a high value on the work values measured, which may have influenced the results. As far as could be established, this finding has not been reported before. Based on the results discussed, the formulated hypothesis, namely that work ethics statistically significantly predict work values, is accepted.

\section{Practical implications}

In order to preserve strong ethical organisational cultures, which are embraced by all organisational members, new employees entering the workplace need to be coached during induction programmes. Moreover, to avoid current employees from engaging in unethical behaviour when appointed in positions of power, it is important to create greater self-awareness, through reflection and engaging in spiritual practices, to develop mindfulness (Keltner, 2016). Furthermore, South African organisations need to consider whether current human resource practices and interventions are still relevant and supportive of the personal values that are subscribed to by the majority of the population. The results also imply that human resource specialists need to consider creative initiatives that will advance the work-life balance of employees.

\section{Limitations and recommendations}

The following caveats are made. First, the study was crosssectional, and data were collected at a specific point in time. In addition, the study was localised, and a non-probability sampling technique was used to generate the sample. As a result, the external validity of the research may be compromised. Caution is advised when generalising the findings to a larger population. Because the research was only conducted in one geographical area in South Africa, it is recommended that the study be replicated nationally.

\section{Conclusion}

As a result of the proliferation of unethical behaviour, and the concomitant decline in work ethics, there is renewed interest in work ethics. However, the contemporary construct of work ethics is based on outdated theories and measuring instruments, which may not be relevant in the current workforce, which is characterised by continual change. In addition, the PWE may not be relevant to the African context.
Furthermore, studying behavioural intent (i.e. work ethics) in isolation from overt behaviour (i.e. work values) may not result in the envisioned change. Based on the results, and particularly as the respondents did not score high on the measured work values, it is recommended that future research should focus not only on work ethics but also on the relationship between work ethics and work values. Thus, it could be concluded that respondents may have the intention to exhibit ethical behaviour, but that this behavioural intent does not seem to find expression in overt behaviour. Therefore, it is important to continue research regarding ethical behavioural intent, since behavioural intent predicts actual behaviour. Future research studies could focus on the relationship between cognitive moral development and behavioural control of employees, and the various individual characteristics and situational factors that may possibly influence this relationship.

\section{Acknowledgements}

This article was language-edited by a freelance language editor, Anthony Sparg. He has edited several academic journal articles and master's theses in the discipline of human resource management. He has an MA cum laude in African Languages (isiXhosa), an MA cum laude in Linguistics and a Higher Diploma in Education.

\section{Competing interests}

The authors declare that they have no financial or personal relationships that may have inappropriately influenced them in writing this article.

\section{Authors' contributions}

P.J., F.v.d.W. and N.S. were equally responsible for the research project, all contributing towards the literature review, data analysis and data interpretation.

\section{References}

Abd-El-Fattah, S.M., \& AL-Nabhani, H.Z. (2012). From self-theories of intelligence to academic delay of gratification: The mediating role of achievement goals. Australian Journal of Educational and Developmental Psychology, 12, 93-107.

Bergh, Z., \& Theron, A. (2009). Psychology in the work context. (4th edn.). Cape Town: Oxford University Press.

Boonzaier, A. (2008). The influence of transactional, transformational leadership on leader-follower value congruence and leadership success. Unpublished master's thesis, University of Stellenbosch, Stellenbosch.

Boshoff, E., \& Van Zyl, E.S. (2011). The relationship between locus of control and ethical behaviour among employees in the financial sector. Koers, 76(2), 283-303. https://doi.org/10.4102/koers.v76i2.17

Bowden, P., \& Smythe, V. (2008). Theories on teaching \& training in ethics. EJBO Electronic Journal of Business Ethics and Organization Studies, 13(2), 19-26.

Bowen, S.A. (2005). A practical model for ethical decision making in issues management and public relations. Journal of Public Relations Research, 17(3), 191-216. https://doi.org/10.1207/s1532754xjprr1703_1

Chidi, O.C., Ogunyomi, O.P., \& Badejo, A.E. (2012). Promoting ethical human resource management practices in work organisations in Nigeria: Roles of HR professionals. International Journal of Human Resource Studies, 2(2), 116-131.

Chun, S., Lee, Y., Kim, B., \& Heo, J. (2012). The impact of leisure participation and leisure satisfaction on stress-related growth. Leisure Sciences, 34(5), 436-449. https://doi.org/10.1080/01490400.2012.714704

Cogin, J. (2012). Are generational differences in work values fact or fiction? Multicountry evidence and implications. The International Journal of Human Resource Management, 23(11), 2268-2294. https://doi.org/10.1080/0958519 2.2011.610967 
Cokley, K., Komarraju, M., Pickett, R., Shen, F., Patel, N., Belur, V. et al., (2007). Ethnic differences in endorsement of the Protestant work ethic: The role of ethnic differences in endorsement of the Protestant work ethic: The role of ethnic
identity and perceptions of social class. The Journal of Social Psychology, 147(1), identity and perceptions of social class. The Journ

Du Plessis, P.J., \& Rousseau, G.G. (2005). Buyer behaviour: A multi-cultural approach. (3rd edn.). Oxford: Oxford University Press.

Dwyer, T. (2012). Legal and ethical issues in the media. Basingstoke, UK: Palgrave Macmillan

Hattrup, K., Mueller, K., \& Joens, I. (2007). The effects of nations and organizations on work value importance: A cross-cultural investigation. Applied Psychology: An International Review, 56(3), 479-499. https://doi.org/10.1111/j.1464 0597.2007.00268.x

Hirschi, A. (2010). Positive adolescent career development: The role of intrinsic and extrinsic work values. Career Development Quarterly, 58(3), 276-287. https://doi. org/10.1002/j.2161-0045.2010.tb00193.x

Ho, C.-C. (2006). A study of the relationships between work values, job involvement and organisational commitment among Taiwanese nurses. Unpublished doctoral and organisational commitment among Taiwanese nurses.
thesis, Queensland University of Technology, Australia.

Horman, M.J., \& Kenley, R. (2005). Quantifying levels of wasted time in construction with meta-analysis. Journal of Construction Engineering and Management, with meta-analysis. Journal of Construction Engineering and Manag
131(1), 52-61. https://doi.org/10.1061/(ASCE)0733-9364(2005)131:1(52)

Ivaniš, M., \& Šturlić, R.M. (2016). Influence of managers personal values and ethical behaviour on business success of hotel entrepreneurs. In Tourism \& Hospitality Industry Conference Proceedings, 28-29 April 2016 (pp. 80-94). Opatija, Croatia.

Jafarkarimi, H., Saadatdoost, R., Sim, A.T.H., \& Hee, J.M. (2016). Behavioral intention in social networking sites ethical dilemmas: An extended model based on theory of planned behavior. Computers in Human Behavior, 62, 545-561. https://doi. org/10.1016/j.chb.2016.04.024

Jones, W.T., Sontag, F., Beckner, M.O., \& Fogelin, R.J. (1977). Approaches to ethics. (3rd edn.). New York: McGraw-Hill.

Jordan, P.J., Werner, A., \& Venter, D. (2015). Achieving excellence in private intensive care units: The effect of transformational leadership and organisational culture on organisational change outcomes. South African Journal of Human Resource Management, 13(1), Art. \#707, 1-10. https://doi.org/10.4102/sajhrm.v13i1.707

Keltner, D. (2016, October 1). Managing yourself: Don't let power corrupt you. Harvard Business Review, 1 October, pp. 112-115.

Kurland, N.B. (1995). Ethical intentions and the theories of reasoned action and planned behavior. Journal of Applied Social Psychology, 25(4), 297-313. https:// doi.org/10.1111/j.1559-1816.1995.tb02393.x

Langley, R., Du Toit, R., \& Herbst, D.L. (1992). Manual for the Values Scale (VS). Pretoria: Human Sciences Research Council.

Leedy, P.D., \& Ormrod, J.E. (2013). Practical research: Planning and design. (10th edn.) Upper Saddle River, NJ: Pearson Education.

Liu, Y., \& Lei, Y. (2012). The connotation of work values: A preliminary review. Asian Social Science, 8(1), 47-53.

Mann, M.J., Taber, T.D., \& Haywood, K.J. (2013). Work ethics revisited: Identification and operationalising new dimensions of work ethic a century after Weber. Journa of Business Discipline, 11(1), 65-101.

McManus, L., \& Subramaniam, N. (2009). Ethical evaluations and behavioural intentions of early career accountants: The impact of mentors, peers and individual attributes. Accounting \& Finance, 49(3), 619-643. https://doi.org/ individual attributes. Accounting \&
10.1111/j.1467-629X.2009.00301.x

Melden, A.I. (1967). Ethical theories: A book of readings. Englewood Cliffs, NJ: Prentice-Hall.

Miller, M.J., Woehr, D.J., \& Hudspeth, N. (2002). The meaning and measurement of work ethic: Construction and initial validation of a multidimensional inventory. Journal of Vocational Behavior, 60(3), 451-489. https://doi.org/10.1006/ jvbe.2001.1838

Montgomery, W. (2011). Human value structure and emotions. Dissertation. Göteborg, Sweden: Department of Psychology, University of Gothenburg.

Niemi, L., \& Young, L. (2013). Caring across boundaries versus keeping boundaries intact: Links between moral values and interpersonal orientations. PLoS One, 8(12), 1-12. https://doi.org/10.1371/journal.pone.0081605

Nord, W.R., Brief, A.P., Atieh, J.M., \& Doherty, E.M. (1990). Studying meanings of work: The case of work values. In A. Brief \& W. Nord (Eds.), Meanings of occupational work: A collection of essays. Lexington, KY: Lexington Books.

O'connor, J.P., \& Kinnane, J.F. (1961). A factor analysis of work values. Journal of Counseling Psychology, 8(3), 263-267. https://doi.org/10.1037/h0047440

Pallant, J. (2011). SPSS survival manual: A step by step guide to data analysis using SPSS. (4th edn.). Canberra, Australia: Allen \& Unwin.

Palmer, S.E. (1983). Authority: An essential part of practice. Social Work: A Journal of the National Association of Social Workers, 28(2), 120-125.

Patel, K. (2013, December 05). Analysis: Perceptions and reality of corruption in South Africa. Daily Maverick. Retrieved August 13, 2014, from http://www. dailymaverick. co.za/article/2013-12-05-analysis-perceptions-and-reality-of-corruption-insouth-africa/\#.U-tpt-OSySo

Pek, C.-K., Lim, Y.-M., \& Yee, A.-P. (2008). Work values of baby-boomers and generation $X$ of the Chinese community in Malaysia. International Journal of Business and Management, 3(10), 147-153.
PwC. (2016). Global Economic Crime Survey 2016. (5th South African edn.). Retrieved October 15, 2016, from http://www.pwc.co.za/en/assets/pdf/south-africancrime-survey-2016.pdf

Quesenberry, L., Woodburne, P.R., \& Yang, C. (2013). Assessment of ethical reasoning at a public university. Journal of Business Disciplines, 11(1), 1-36.

Quick, J.C., \& Nelson, D.L. (2011). Principles of organizational behavior: Realities and challenges. (7th edn.). Mason, $\mathrm{OH}$ : South-Western.

Ravangard, R., Sajjadnia, Z., Jafari, A., Shahsavan, N., Bahmaie, J., \& Bahadori, M. (2014). The association between work ethics and attitudes towards organizational changes among the administrative, financial and support employees of genera teaching hospitals. Journal of Medical Ethics and History of Medicine, 7(12), 1-9.

Richards, C.H., Gilbert, J., \& Harris, J.R. (2002). Assessing ethics education needs in the MBA program. Teaching Business Ethics, 6(4), 447-476. https://doi.org/10.1023/A: 1021183009537

Rogojan, P.T. (2009). Deviant workplace behavior in organizations: Antecedents, influences and remedies. Master's dissertation, University Wien, Austria.

Rohan, M.J. (2000). A rose by any name? The values construct. Personality and Social Psychology Review, 4, 255-277.

Ros, M., Schwartz, S.H., \& Surkiss, S. (1999). Basic individual values, work values, and the meaning of work. Applied Psychology: An International Review, 48(1), 49-71. https://doi.org/10.1111/j.1464-0597.1999.tb00048.x

Salamzadeh, Y., Nejati, M., \& Salamzadeh, A. (2014). Agility path through work values in knowledge-based organizations: A study of virtual universities. Innovar, 24(53), 177-186. https://doi.org/10.15446/innovar.v24n53.43942

Salkind, N.J. (Ed.). (2012). Exploring research. (8th edn.). New York: Pearson.

Schreuder, A.M.G., \& Coetzee, M. (2011). Careers: An organisational perspective. (4th edn.). Cape Town: Juta.

Schwartz, S.H., \& Bilsky, W. (1990). Toward a theory of the universal content and structure of values: Extensions and cross-cultural replications. Journal of Personality and Social Psychology, 58(5), 878-891. https://doi.org/10.1037/00223514.58.5.878

Sergio, R.P., Dungca, A.L., \& Ormita, L.A.G-L. (2015). The demographic variables and emotional intelligence as correlates of work values: A cross-cultural examination towards organizational change. Journal of Economics, Business and Management, 3(2), 167-175. https://doi.org/10.7763/JOEBM.2015.V3.175

Steyn, C., \& Kotze, H. (2004). Work value change in South Africa between 1995 and 2001: Race, gender and occupations compared. South African Journal of Labour Relations, 28(1), 4-33.

Stones, C.R., \& Philbrick, J.L. (2001). Work attitudes among a sample of Black South African students. The Journal of Social Psychology, 132(2), 281-284. https://doi.or $\mathrm{g} / 10.1080 / 00224545.1992 .9922984$

Tang, T.L.-P. (1990). Factors affecting intrinsic motivation among university students in Taiwan. The Journal of Social Psychology, 130(2), 219-230. https://doi.org/10.1080/ 00224545.1990 .9924572

Twenge, J.M., Campbell, S.M., Hoffman, B.J., \& Lance, C.E. (2010). Generational differences in work values: Leisure and extrinsic values increasing, social and intrinsic values decreasing. Journal of Management, 36(5), 1117-1142. https:// doi.org/10.1177/0149206309352246

Uçanok, B. (2008). The effects of work values, work-value congruence and work centrality on organizational citizenship behavior International Journal of Behavioral, Cognitive, Educational and Psychological Sciences, 1(1), 1-14.

Ueda, Y., \& Ohzono, Y. (2013). Differences in work values by gender, marital status, and generation: An analysis of data collected from "Working Persons Survey, 2010." International Journal of Human Resource Studies, 3(2), 28-41. https://doi. org/10.5296/ijhrs.v3i2.3131

Van der Walt, F., \& De Klerk, J.J. (2015). The experience of spirituality in a multicultural and diverse environment. Journal of Asian and African Studies, 14(4), 253-288. https://doi.org/10.1163/15692108-12341346

Van der Walt, F., Jonck P., \& Sobayeni, N.C. (2016). Work ethics of different generational cohorts in South Africa. African Journal of Business Ethics, 10(1), 52-66.

Van Ness, R.K., Melinsky, K., Buff, C.L., \& Seifert, C.F. (2010). Work ethic: Do new employees mean new work values? Journal of Managerial Issues, 22(1), 10-34.

Van Vuuren, L.J. (2002). Institutionalising business ethics: A multi-level ethics strategy. Management Dynamics, 2(2), 21-27.

Vyas-Doorgapersad, S. 2007. Corruption in the public sector: A comparative analysis. Journal of Public Administration, 42(5), 285-299.

Wagner, C., Kawulich, B., \& Garner, M. (Eds.). (2012). Doing social research: A global context. Maidenhead, UK: McGraw-Hill Higher Education.

Wils, T., Saba, T., Waxin, M.-F., \& Labelle, C. (2011). Intergenerational and intercultura differences in work values in Quebec and the United Arab Emirates. Industria Relations, 66(3), 445-469. https://doi.org/10.7202/1006347ar

Wittmer, D.P. (2000). Ethical sensitivity in management decisions: Developing and testing a perceptual measure among management and professional student groups. Teaching Business Ethics, 4(2), 181-205. https://doi.org/10.1023/A 1009866315139

Wong, S.-W., \& Yuen, M. (2015). Super's work value inventory: Issues of subtest internal consistency using a Chinese university student sample in Hong Kong. Journal of Employment Counseling, 52(1), 29-35. https://doi.org/10.1002/j.21611920.2015.00054.x 